\title{
Inactivation of Human $\alpha$-1-Antitrypsin by a Tissue-destructive Protease of Legionella pneumophila
}

\author{
By J. W. CONLAN,* A. Williams and L. A. E. ASHWORTH \\ Experimental Pathology Laboratory, PHLS Centre for Applied Microbiology and Research, \\ Porton Down, Salisbury, Wiltshire SP4 0JG, UK
}

(Received 10 August 1987; revised 22 October 1987)

\begin{abstract}
Three extracellular proteases produced by Legionella pneumophila during growth in liquid medium were examined for their effects on human $\alpha$-1-antitrypsin $(\alpha-1-\mathrm{AT})$. One of these proteases, tissue-destructive protease (TDP) destroyed completely the trypsin-inhibitory capacity of $\alpha-1-\mathrm{AT}$ at protease :inhibitor molar ratios down to $0.002: 1$. After inactivation by TDP, the $M_{\mathrm{r}}$ of $\alpha-1-\mathrm{AT}$ was reduced by 5000 in SDS-PAGE. This suggested that inactivation entailed only limited cleavage.
\end{abstract}

\section{INTRODUCTION}

$\alpha$-1-Antitrypsin ( $\alpha$-1-AT) is the major protease inhibitor found in human serum (Travis \& Johnson, 1981). Human $\alpha-1-\mathrm{AT}$ is a specific inhibitor of serine proteases, including leucocyte elastase, pancreatic trypsin and chymotrypsin, cathepsin G, collagen and kallikrein. The main role of $\alpha-1-\mathrm{AT}$ is the control of tissue destruction by these endogenous serine proteases.

Pseudomonas aeruginosa (Morihara et al., 1979) and Serratia marcescens (Molla et al., 1986) elaborate non-serine metalloproteases which are capable of inactivating $\alpha-1$-AT by specific cleavage. It has been postulated that this provides a mechanism which may contribute to the pathogenesis of the diseases, including bronchopneumonias, caused by these organisms.

A number of extracellular proteolytic activities have been described for Legionella pneumophila. In particular, Müller (1983) has described proteolytic activity against serum proteins by $L$. pneumophila when this organism was cultured on medium containing human serum. Müller demonstrated degradation of $\alpha-1-\mathrm{AT}$ by a change in electrophoretic mobility using an immunoelectrophoretic technique.

Recently, six discrete extracellular proteolytic activities were isolated from L. pneumophila grown in broth culture (Conlan et al., 1986). In the present study a lysine aminopeptidase (lysAP), a leucine-AP and a tissue-destructive protease (TDP) of L. pneumophila, chosen on the basis of their relative abundance in culture supernates, were examined for their effect on $\alpha-1-\mathrm{AT}$.

\section{METHODS}

Enzymes. L. pneumophila proteases were obtained as described below. leu-AP and lys-AP were assayed using leucine $p$-nitroanilide (leu-pNA) and lysine-pNA substrates (Sigma), respectively. These were dissolved to $1 \mathrm{~mm}$ in $50 \mathrm{~mm}$-Tris/ $\mathrm{HCl} \mathrm{pH} \mathrm{7.0} \mathrm{(buffer} \mathrm{A)} \mathrm{and} \mathrm{stored} \mathrm{at} 4{ }^{\circ} \mathrm{C}$. For quantification of enzyme activity, $50 \mu$ lof enzyme was added to $2.5 \mathrm{ml}$ substrate (at $37^{\circ} \mathrm{C}$ ) in a $1 \mathrm{~cm}$ cuvette. Using heat-inactivated enzyme as a blank, increase in absorbance at $405 \mathrm{~nm}$ with time was measured in a spectrophotometer (Philips PU8720) with a sample compartment at $37^{\circ} \mathrm{C}$. TDP activity was quantified using hide powder azure (Calbiochem) as substrate. TDP $(50 \mu \mathrm{l}$; diluted in buffer $\mathrm{A})$ was added to a $5 \mathrm{ml}$ suspension of hide powder $\left(10 \mathrm{mg} \mathrm{ml}^{-1}\right.$ in buffer A) which had been pre-warmed to $37^{\circ} \mathrm{C}$. Incubation at $37^{\circ} \mathrm{C}$ was continued for $20 \mathrm{~min}$ and the reaction stopped by placing on

Abbreviations: $\alpha$-1-AT, $\alpha$-1-antitrypsin; TDP, tissue-destructive protease; AP, aminopeptidase; $p$ NA, $p$ nitroanilide; BAPNA, $N \alpha$-benzoyl-DL-arginine $p$-nitroanilide; FPLC, fast protein liquid chromatography. 
ice. The remaining particulate substrate was removed by filtration (Whatman no. 1 filter) and absorbance of the coloured filtrate read at $595 \mathrm{~nm}$ in a $1 \mathrm{~cm}$ cuvette.

Bovine trypsin (Sigma type 1) was prepared as a $5 \mathrm{mg} \mathrm{ml}^{-1}$ stock solution in $1 \mathrm{~mm}-\mathrm{HCl}$ and stored at $4{ }^{\circ} \mathrm{C}$. Trypsin substrate was $N \alpha$-benzoyl-DL-arginine $p$-nitroanilide (BAPNA). This was dissolved in dimethyl sulphoxide and diluted to $1 \mathrm{mM}$ in $100 \mathrm{mM}-\mathrm{Tris} / \mathrm{HCl}, 10 \mathrm{mM}-\mathrm{CaCl}_{2}, \mathrm{pH} 7.8$ (buffer B). Trypsin activity was determined as for leu-AP above.

Enzyme units. One unit of enzyme activity was arbitrarily defined as the amount of enzyme which, in the appropriate assay (above), caused an increase in absorbance of $0.01 \mathrm{~min}^{-1}$ at $37^{\circ} \mathrm{C}$. Protein was determined by absorbance at $280 \mathrm{~nm}$. On this basis the specific activities [units (mg protein) ${ }^{-1}$ ] of the enzymes used in the present investigation were determined to be as follows: trypsin (525), TDP (180), leu-AP (5800), lys-AP (8300).

Organism. Corby strain Legionella pneumophila was a serogroup 1 human isolate, kindly provided by $\mathrm{Dr} \mathrm{R}$. A. Swann, John Radcliffe Hospital, Oxford, UK. This organism had been passaged four times on charcoal yeast extract (CYE) agar (Edelstein, 1981) before use in the present study.

Preparation of L. pneumophila proteases. Concentrated culture supernatant fractions of L. pneumophila grown in yeast extract broth (YEB; Ristroph et al., 1980) were prepared as previously described (Conlan et al., 1986) except that the yeast extract component of the medium was ultrafiltered through a YM10 membrane (Amicon; $M_{\mathrm{r}}$ cut-off $>10000$ ) to remove high $-M_{\mathrm{r}}$ material before inoculation. It has been reported that this procedure facilitates the purification of extracellular proteases of $L$. pneumophila (Dreyfus \& Iglewski, 1986). Individual proteases present in concentrated culture supernates ( $10 \mathrm{ml}$ of 100 -fold concentrated supernate) were separated by Sephadex G100 gel-filtration and DEAE-cellulose ion-exchange chromatography as previously described (Conlan et al., 1986). Proteases separated by ion-exchange chromatography on DEAE-cellulose were further purified by fast protein liquid chromatography (FPLC) as follows. Samples $(10 \mathrm{ml})$ of individual proteases were mixed with $40 \mathrm{ml}$ buffer A and applied to a $1 \mathrm{ml}$ Mono Q (Pharmacia) anion-exchange column using a $50 \mathrm{ml}$ sample loop. The sample was eluted with a linear gradient of $\mathrm{NaCl}(0-0.5 \mathrm{M}$, generated over $50 \mathrm{ml})$ in buffer $\mathrm{A}$ at a flow rate of $2 \mathrm{ml} \mathrm{min}^{-1}$ and $1 \mathrm{ml}$ fractions collected. Individual fractions were monitored for protease activity using specific substrates (Conlan et al., 1986). FPLC fractionated proteases were stored at $-70^{\circ} \mathrm{C}$, without further treatment, until required.

Degradation of $\alpha-1-A T$ by L. pneumophila proteases. Human $\alpha-1-\mathrm{AT}$ was from Sigma. For these experiments the following $M_{\mathrm{r}}$ values were assumed: trypsin and $\alpha-1-\mathrm{AT}, M_{\mathrm{r}} 25000$ and 58000 respectively (Morihara et al., 1979); $L$. pneumophila lys-AP, leu-AP and TDP, $M_{\mathrm{r}} 34000,35000$ and 40000 respectively (by SDS-PAGE). Individual Legionella proteases were mixed in a molar ratio enzyme : $\alpha$-1-AT of $0: 1,0 \cdot 1: 1,0.02: 1,0.002: 1$ and $0.001: 1$. The reaction mixture, which consisted of $10 \mu \mathrm{l}$ of enzyme and $15 \mu \mathrm{l}(8 \mu \mathrm{g}) \alpha-1-\mathrm{AT}$ in buffer $\mathrm{A}$, was incubated for $30 \mathrm{~min}$ at $37^{\circ} \mathrm{C}$. Trypsin $(4 \mu \mathrm{g}$ in $25 \mu \mathrm{l}$ buffer $\mathrm{B})$ was then added to the mixture and the incubation continued for $10 \mathrm{~min}$. BAPNA $(2.5 \mathrm{ml})$ was then added and the mixture was incubated for a further $10 \mathrm{~min}$. The reaction was then stopped by placing the mixture on ice, the absorbance at $405 \mathrm{~nm}$ determined and the remaining trypsin-inhibitory capacity calculated. Controls were $\alpha-1$-AT pre-incubated with buffer A or heat-inactivated Legionella protease $\left(100^{\circ} \mathrm{C}\right.$ for $\left.5 \mathrm{~min}\right)$ prior to addition of trypsin. Preliminary experiments demonstrated no activity of Legionella proteases against BAPNA. Pre-incubation of trypsin with Legionella proteases did not affect its activity against BAPNA.

Effect of TDP on pre-formed trypsin- $\alpha-1-A T$ complex. $\alpha-1-\mathrm{AT}(8 \mu \mathrm{g}$ in $15 \mu \mathrm{l}$ buffer $\mathrm{B})$ was mixed with $4 \mu \mathrm{g}$ trypsin in $25 \mu \mathrm{l}$ of the same buffer and incubated at $37^{\circ} \mathrm{C}$. After $10 \mathrm{~min}, 10 \mu \mathrm{TDP}\left(55 \mu \mathrm{g} \mathrm{ml}^{-1}\right)$ was added to the reaction mixture and the incubation continued for $30 \mathrm{~min}$. Residual trypsin activity was determined by addition of $2.5 \mathrm{ml}$ BAPNA for a further $10 \mathrm{~min}$, as above. Controls were run in which TDP was replaced either by heat-inactivated TDP or buffer A, or $\alpha-1$-AT was replaced by buffer $B$.

$S D S-P A G E$ analysis of inactivation of $\alpha-1-A T$ by TDP. TDP was mixed with $\alpha-1-\mathrm{AT}$ at a ratio of $0 \cdot 02: 1$ and the mixture was incubated for $30 \mathrm{~min}$ at $37^{\circ} \mathrm{C}$. The reaction mixture was then mixed with an equal volume of sample buffer $(10 \%, \mathrm{v} / \mathrm{v}$, glycerol, $2 \%$, w/v, SDS, $5 \%$, v/v, mercaptoethanol, $0.001 \%, \mathrm{w} / \mathrm{v}$, bromophenol blue in $62.5 \mathrm{mM}-$ Tris/ $\mathrm{HCl}, \mathrm{pH} \mathrm{6.8)}$ and boiled for $5 \mathrm{~min}$. Samples and $M_{\mathrm{r}}$ markers (Sigma) were separated by SDS-PAGE, incorporating a $12 \%(\mathrm{w} / \mathrm{v})$ separating gel, using the Laemmli buffer system (Laemmli, 1970). Electrophoresis was for $20 \mathrm{~h}$ at $8 \mathrm{~mA}$ constant current, after which gels were stained with Coomassie brilliant blue.

Effect of TDP on trypsin-inhibitory capacity of serum. Human serum was obtained from healthy volunteers and stored at $-70^{\circ} \mathrm{C}$ as $1 \mathrm{ml}$ samples until required. Serum $\alpha$-1-AT content was determined using a commercial radial immunodiffusion assay (Partigen; Behringwerke). Doubling dilution series of thawed sera ( $25 \mu$ l through $25 \mu \mathrm{l}$ volumes buffer B) were made in 96-well microtitration plates. TDP $\left(25 \mu \mathrm{l}\right.$ at $\left.55 \mu \mathrm{g} \mathrm{m}^{-1}\right)$ was then added to each well and the plates were incubated for $30 \mathrm{~min}$. Trypsin ( $50 \mu \mathrm{l}$ of a 1 in 40 dilution of stock in buffer A) was added to each well and incubation continued for $30 \mathrm{~min}$. Remaining trypsin-inhibitory capacity was measured by adding $150 \mu \mathrm{l}$ BAPNA per well, incubating plates for a further $10 \mathrm{~min}$ and reading them in a photometer (Titertek Multiscan) fitted with a filter at $405 \mathrm{~nm}$. Controls, which consisted of heat-inactivated TDP, were included for each serum. The effect of TDP on trypsin-inhibitory capacity was further examined by fractionating TDP-treated 
serum by FPLC. Serum ( $250 \mu \mathrm{l}$ of a 1 in 4 dilution in buffer A) was incubated with $250 \mu 1$ TDP ( $\left.55 \mu \mathrm{g} \mathrm{ml}^{-1}\right)$. After $30 \mathrm{~min}$ at $37^{\circ} \mathrm{C}$ the reaction mixture was diluted with an equal volume of $25 \mathrm{~mm}$-Tris/ $\mathrm{HCl} \mathrm{pH} 8.5$ (buffer C) and $500 \mu \mathrm{l}$ was separated by ion-exchange using a Mono $\mathrm{Q}$ column as described below.

Fractionation of human sera by FPLC. Neat serum $(50 \mu \mathrm{l})$ was diluted 1 in 20 in buffer $\mathrm{C}$ and a $500 \mu \mathrm{l}$ sample was applied to a $1 \mathrm{ml}$ Mono $\mathrm{Q}$ column. The sample was eluted with a linear gradient of $\mathrm{NaCl}(0-0.5 \mathrm{M}$ in buffer $\mathrm{C}$ generated over $40 \mathrm{ml}$ ) at a flow rate of $2 \mathrm{ml} \mathrm{min}^{-1}$ and $1 \mathrm{ml}$ fractions were collected. Human $\alpha-1-\mathrm{AT}$ and $\alpha-2-$ macroglobulin (Sigma) were run separately by the same method as standards. Anti-trypsin activity of FPLC fractions was determined in 96 -well plates as follows. Each serum fraction $(50 \mu \mathrm{l})$ was mixed with $50 \mu \mathrm{l}$ trypsin $(1$ in 400 dilution of stock in buffer A) and incubated for $30 \mathrm{~min}$ at $37^{\circ} \mathrm{C}$. After addition of $150 \mu$ l BAPNA to each well, plates were incubated for a further $10 \mathrm{~min}$ and absorbance at $405 \mathrm{~nm}$ was measured. Inhibitory activity of serum fractions for leu-AP and lys-AP was similarly determined using specific substrates and 1 in 20 dilutions of stock enzymes. The uneven size of hide powder particles rendered this substrate unsuitable for use in plate assays for TDP activity. Therefore, Azocoll (Sigma) substrate was used instead. This insoluble substrate was prepared in buffer $A\left(10 \mathrm{mg} \mathrm{ml}^{-1}\right)$ and kept in suspension by stirring during dispensing. Following incubation of serum fractions with TDP ( 1 in 20 dilution of $55 \mu \mathrm{g} \mathrm{ml}^{-1}$ frozen stock in buffer $\mathrm{A}$ ), $100 \mu$ l volumes of the reaction mixture were transferred to the corresponding wells of a second plate which contained $150 \mu$ l Azocoll substrate per well. The second plate was incubated for $30 \mathrm{~min}$ at $37^{\circ} \mathrm{C}$, then $200 \mu$ l volumes were carefully withdrawn to a third plate, avoiding disturbance of remaining sedimented substrate, and this plate was read at $492 \mathrm{~nm}$.

\section{RESULTS}

\section{Trypsin-inhibitory capacity of serum fractions separated by FPLC}

Serum fractionated by FPLC, using a Mono $\mathrm{Q}$ anion-exchange column, produced a complex profile of absorbance at $280 \mathrm{~nm}$ (Fig. 1a). Trypsin inhibition assays demonstrated that inhibitory activity (Fig. $1 b$ ) co-eluted with a peak of absorbance at $280 \mathrm{~nm}$ (Fig. $1 a$ ). This peak eluted in the same volume as purified human $\alpha-1$-AT (Fig. 1a). None of the L. pneumophila proteases were inhibited by this material. $\alpha$-2-Macroglobulin, another serum protease inhibitor, was not associated with $\alpha-1$-AT but eluted in later fractions which also did not inhibit any of the test proteases. The peaks and troughs of proteolytic activity observed in regions of the profile remote from fractions containing $\alpha-1-\mathrm{AT}$ activity were also seen with blank $\mathrm{NaCl}$ gradients. The separation and trypsin-inhibition profiles were very reproducible and gave identical results for each of four test sera.

\section{Effect of L. pneumophila proteases on inhibitory capacity of $\alpha-1-A T$ for trypsin}

When purified $\alpha-1$-AT was pre-incubated with the $L$. pneumophila proteases TDP, leu-AP and lys-AP, only TDP had an effect on the inhibitory capacity of $\alpha-1-\mathrm{AT}$ for trypsin under the assay conditions used. Because of this finding all further experimentation was confined to TDP. At TDP : inhibitor molar ratios down to $0.002: 1$ there was complete destruction of trypsininhibitory capacity; even at the lower TDP : inhibitor ratio $0.001: 1, \alpha-1$-AT retained only $25 \%$ of initial inhibitory capacity.

\section{$S D S-P A G E$ analysis of $\alpha-I-A T$ inactivation by TDP}

SDS-PAGE was used to determine the nature of the inactivation of $\alpha-1-A T$ by TDP of $L$. pneumophila. Inactivation of $\alpha-1-\mathrm{AT}$ gave rise to a single polypeptide band with an $M_{\mathrm{r}} 5000$ lower than that of the active inhibitor (Fig. 2).

Stability of $\alpha-1-A T-$ trypsin complex in the presence of TDP

The complex formed between $\alpha-1-\mathrm{AT}$ and trypsin in the absence of TDP was stable upon incubation with the latter; trypsin activity was not regenerated in the presence of TDP.

\section{Effect of TDP on trypsin-inhibitory capacity of serum}

The levels of $\alpha-1$-AT present in the sera used in these experiments were within the range 2.48$2.72 \mathrm{mg} \mathrm{ml}^{-1}$. L. pneumophila TDP caused destruction of $\alpha-1-\mathrm{AT}$ present in normal human serum. A marked decrease in the trypsin-inhibitory capacity of whole serum was observed following incubation with TDP. Total inactivation of trypsin-inhibitory capacity occurred at TDP : $\alpha-1$-AT ratios above $0 \cdot 1: 1$. This decrease in trypsin-inhibitory capacity was of a similar 

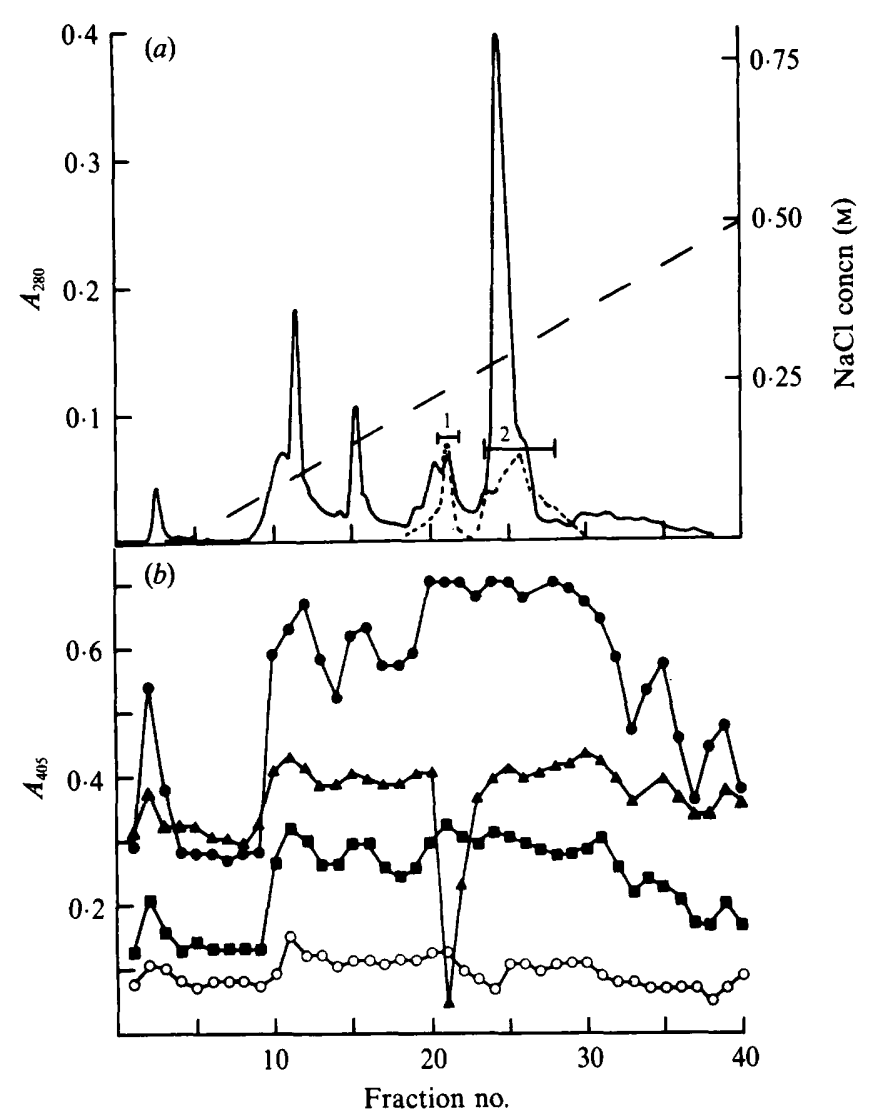

Fig. 1. Anti-protease activity of normal human serum. (a) Whole human serum was fractionated by FPLC on a Mono Q column according to Methods. Standards (broken peaks) were $\alpha-1$-AT (1) and $\alpha-2$ macroglobulin (2). - - , $\mathrm{NaCl}$ gradient. (b) Individual serum fractions were assayed for protease inhibitory capacity against trypsin $(\boldsymbol{\Lambda})$, leu-AP $(\boldsymbol{O})$, lys-AP $(\boldsymbol{\Xi})$ and TDP $(O)$.

order for each of four test sera. No decrease in $\alpha-1-\mathrm{AT}$, measured as antigen by radial immunodiffusion in gel, was observed in sera treated with TDP.

When TDP-treated serum was fractionated by FPLC, loss of trypsin-inhibitory capacity was accompanied by partial loss of the peak of absorbance at $280 \mathrm{~nm}$ associated with $\alpha-1$-AT (Fig. $3 b, c)$. The protein profiles obtained for serum treated with either TDP or heat-inactivated $\left(100{ }^{\circ} \mathrm{C}\right.$ for $\left.5 \mathrm{~min}\right) \mathrm{TDP}$ (Fig. $\left.3 a, b\right)$ exhibited a peak at the start of the gradient which represented a shift in the profile obtained with untreated serum (Fig. 1a). This shift was probably due to the higher salt concentration of the TDP-treated samples; the TDP eluted from Mono Q in $0.4 \mathrm{M}-\mathrm{NaCl}$ and was used without further treatment to avoid loss of activity.

\section{DISCUSSION}

Three extracellular proteases purified from broth culture supernates of L. pneumophila were examined for their effects on the serine protease inhibitor $\alpha-1-\mathrm{AT}$. None of the Legionella proteases were inhibited by $\alpha-1-\mathrm{AT}$; these proteases are resistant to inhibition by phenylmethylsulphonyl fluoride (Conlan, 1987; S. Simpson, personal communication) which is a specific inhibitor of serine proteases. One of the Legionella proteases, TDP, destroyed completely the trypsin-inhibitory capacity of purified $\alpha-1-\mathrm{AT}$ at low protease :inhibitor molar ratios. The $M_{\mathrm{r}}$ of $\alpha-1-\mathrm{AT}$ treated with TDP was 5000 lower than that of native $\alpha-1-\mathrm{AT}$, a decrease 


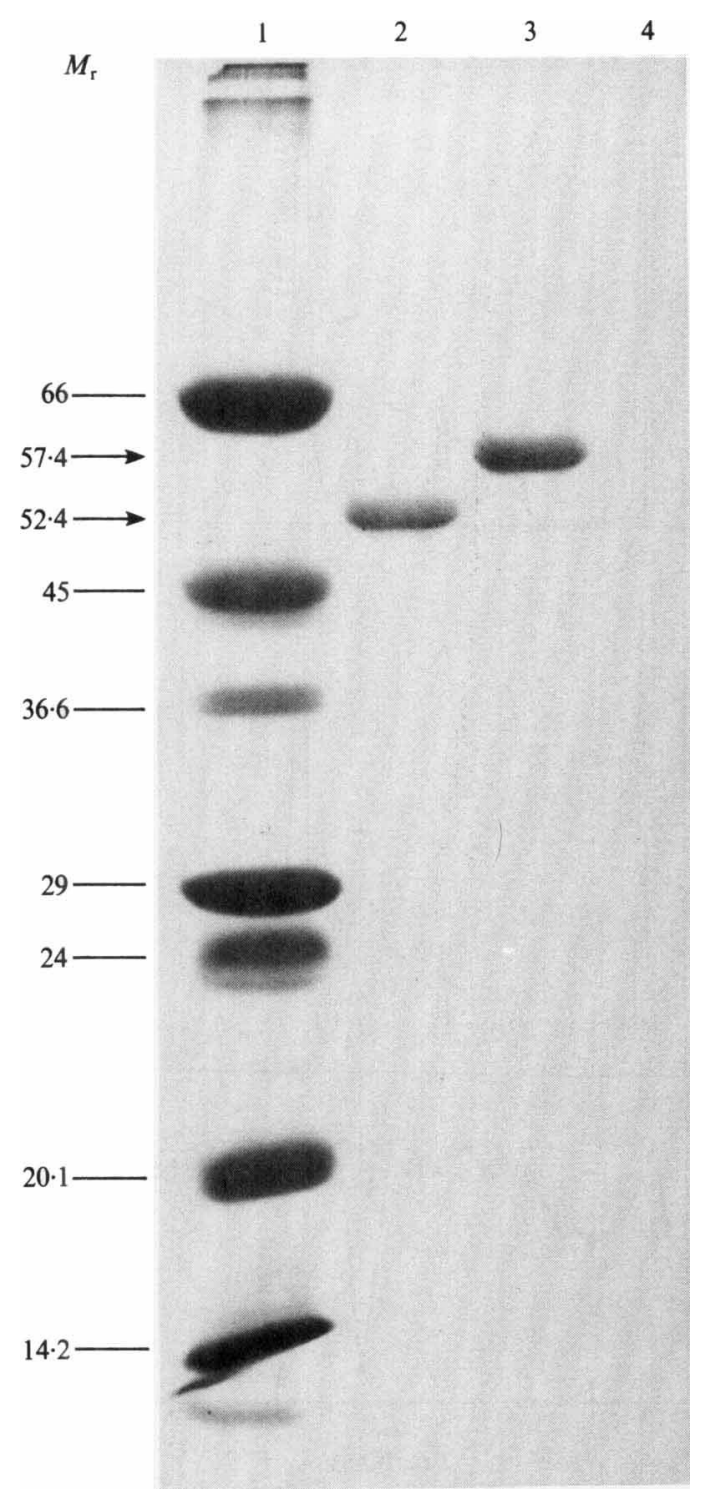

Fig. 2. SDS-PAGE analysis of $\alpha-1-\mathrm{AT}$ inactivated by reaction with $L$. pneumophila TDP. Lane $1, M_{\mathrm{r}}$ markers; lane 2, $\alpha-1-\mathrm{AT}$ incubated with TDP for $30 \mathrm{~min}$ at $37^{\circ} \mathrm{C}$ at a protease : inhibitor molar ratio of $0.02: 1$; lane 3, $\alpha-1-A T$ incubated as above in the absence of TDP; lane 4, TDP at the test concentration.

identical to that observed with $\alpha-1$-AT treated with $P$. aeruginosa elastase (Morihara et al., 1979) and $S$. marcescens metalloprotease (Molla et al., 1986). This uniform decrease in $M_{\mathrm{r}}$ indicates that $\alpha-1-\mathrm{AT}$ is inactivated by proteolysis at a specific cleavage point. Also, TDP inactivated $\alpha-1$-AT present in normal human serum, although only at higher molar ratios of protease :inhibitor than those effective with purified $\alpha-1-\mathrm{AT}$. This could be due to other serum proteins acting as substrate for TDP in competition with $\alpha-1-\mathrm{AT}$. Once trypsin was bound by $\alpha-1-\mathrm{AT}$, the resultant complex was stable to treatment with TDP. Thus, to exert an effect in vivo, TDP would have to inactivate $\alpha-1-\mathrm{AT}$ before the inhibitor could complex with serine proteases. 


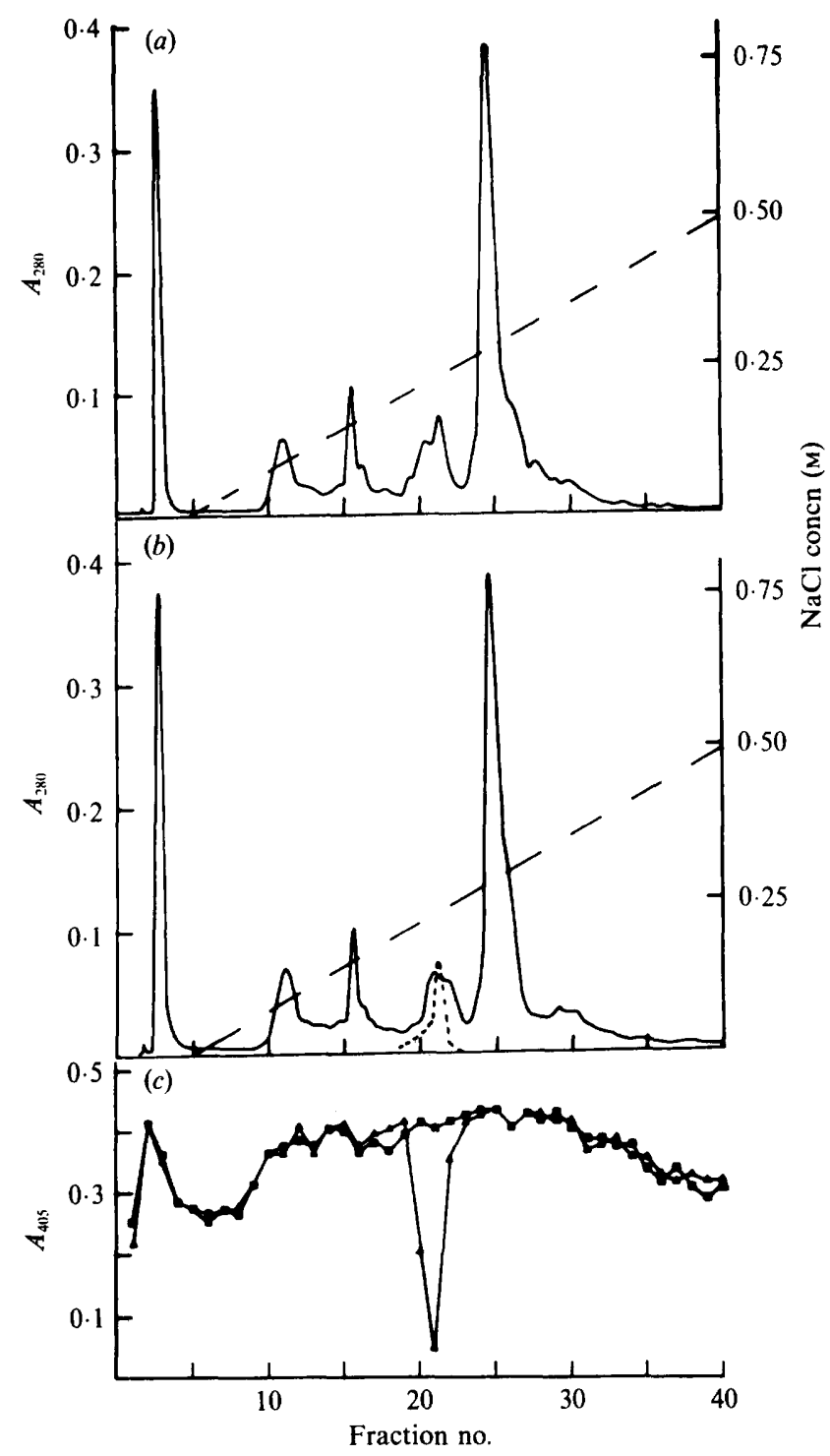

Fig. 3. FPLC analysis of the effect of TDP on the trypsin-inhibitory capacity of normal human serum. (a) Protein profile of serum treated with heat-inactivated TDP and fractionated by FPLC.,$--- \mathrm{NaCl}$ gradient. (b) Protein profile of serum treated with active TDP and fractionated by FPLC. Broken peak, $\alpha$-1-AT standard; - - , NaCl gradient. (c) Inhibitory capacity for trypsin of serum fractions following treatment of whole sera with TDP $(\boldsymbol{\square})$ or heat-inactivated TDP $(\boldsymbol{\Delta})$ was determined as described in Methods.

TDP causes pulmonary lesions similar to those observed in human and experimental Legionnaires' disease (Baskerville et al., 1986; Conlan et al., 1986). This protease has also been demonstrated in the lungs of guinea-pigs exposed to lethal aerosols of L. pneumophila (Williams et al., 1987; Conlan, 1987). Furthermore, TDP was detected in the lungs of these experimental animals in amounts equivalent to the lethal dose of this purified protease administered by the intranasal route (Baskerville et al., 1986). Against this background of massive tissue-destructive activity of the bacterial protease it is difficult to judge the relative importance of $\alpha$-1-AT 
inactivation as a pathogenetic mechanism in Legionnaires' disease. However, extensive necrosis of host inflammatory cells and alveolar epithelium is observed during the course of Legionnaires' disease (Blackmon et al., 1981; Winn \& Myerowitz, 1981). Host proteases released by this necrosis would have the potential to cause further pulmonary damage were they not inhibited by $\alpha-1-\mathrm{AT}$. Reduced levels of anti-protease activity have been demonstrated in the lungs of smokers (Gadek et al., 1979) and in the lungs of patients, mainly elderly and with underlying disease, suffering from a variety of bacterial pneumonias (Abrams et al., 1984). This may, in part, explain the increased susceptibility to Legionnaires' disease of these high-risk individuals.

The levels of $\alpha-1-\mathrm{AT}$ present in the lungs of guinea-pigs with L. pneumophila infections should be quantified. With this information it may be possible to predict the extent of $\alpha-1-\mathrm{AT}$ inactivation by the amounts of TDP known to be present in the lungs of these animals during the course of infection. The effects of Legionella proteases on other host proteins, of potential relevance to the pathogenesis of Legionnaires' disease, are currently under investigation.

This work was funded by an MRC project grant. We thank Dr D. A. Rutter for collection of human sera.

\section{REFERENCES}

Abrams, W. R., Fein, A. M., Kucich, U., Kueppers, F., Yamada, H., Kuzmowycz, T., Morgan, L., Lippmann, M., GoldberG, S. K. \& Weinbaum, G. (1984). Proteinase inhibitory function in inflammatory lung disease. American Review of Respiratory Disease 129, 735-741.

Baskerville, A., Conlan, J. W., Ashworth, L. A. E. \& DowseTT, A. B. (1986). Pulmonary damage caused by a protease from Legionella pneumophila. British Journal of Experimental Pathology 67, 527536.

Blackmon, J. A., Chandler, F. W., Cherry, W. B., England, A. C., Feeley, J. C., Hicklin, M. D., MCKinNeY, R. M. \& Wilkinson, H. W. (1981). Legionellosis. American Journal of Pathology 103, 429-465.

Conlan, J. W., Baskerville, A. \& Ashworth, L. A. E. (1986). Separation of Legionella pneumophila proteases and purification of a protease which produces lesions like those of Legionnaires' disease in guinea pig lung. Journal of General Microbiology 132, 1565-1574.

CONLAN, J. W. (1987). Studies of lipopolysaccharide and extracellular proteases from Legionellae of differing virulence. PhD thesis, PHLS, CAMR, Porton Down, Salisbury, UK (CNAA).

Dreyfus, L. A. \& Iglewski, B. H. (1986). Purification and characterisation of an extracellular protease of Legionella pneumophila. Infection and Immunity 51, 736-743.

EDELSTEIN, P. H. (1981). Improved semi-selective medium for isolation of Legionella pneumophila from contaminated clinical and environmental specimens. Journal of Clinical Microbiology 14, 298303.

Gadek, J. E., Fells, G. A. \& Crystal, R. (1979).
Cigarette smoke induces functional antiproteinase deficiency in the lower respiratory tract of humans. Science 206, 1316-1326.

LAEMMLI, U. K. (1970). Cleavage of structural proteins during the assembly of the head of bacteriophage T4. Nature, London 227, 680-684.

Molla, A., Matsumoto, K., Oyamada, I., Katsuki, T. \& MAEDA, H. (1986). Degradation of protease inhibitors, immunoglobulins and other serum proteins by Serratia protease and its toxicity to fibroblasts in culture. Infection and Immunity 53, 522-529.

Morihara, K., Tsuzukı, H. \& OdA, K. (1979). Protease and elastase of Pseudomonas aeruginosa: inactivation of human plasma $\alpha$-1-proteinase inhibitor. Infection and Immunity 24, 188-193.

MülleR, H. E. (1983). Induction of proteinases in Legionella by growth on agar containing serum. Zentralblatt für Bakteriologie, Mikrobiologie und Hygiene 256, 211-221.

Ristroph, J. D., Hedlund, K. W., \& Allen, R. G. (1980). Liquid medium for growth of Legionella pneumophila. Journal of Clinical Microbiology 11, 19 . 21.

Travis, J. \& Johnson, D. (1981). Human $\alpha-1$ proteinase inhibitor. Methods in Enzymology 80, 754-765.

Williams, A., Baskerville, A., Dowsett, A. B. \& Conlan, J. W. (1987). Immunocytochemical demonstration of the association between L. pneumophila, its tissue-destructive protease and pulmonary lesions in experimental Legionnaires' disease. Journal of Pathology 53 (in the Press).

Winn, W. C. \& Myerowitz, R. L. (1981). The pathology of the Legionella pneumonias. Human Pathology 12, 401-422. 